\title{
A REVIEW ON PHYTO CHEMICALS AND MEDICINAL PROPRTIESOF BOMBAX AND PHYLLANTHUS SPECIES
}

\author{
Pushpita Mohapatra \\ M. Tech \\ IAMR, Ghaziabad (U.P.)
}

\author{
Anshu Sharma \\ M. Tech \\ IAMR, Ghaziabad (U.P.)
}

\author{
Dr. Yamini Dixit \\ Assistant Professor \\ IAMR, Ghaziabad (U.P.)
}

\begin{abstract}
Plants are showing very great effects on humans across the globe. Bombax and Phyllanthus species are common plant species exhibiting medicinal properties and are widely used for their therapeutic values. Bombax is a genus which belongs to family Malvaceae. It is an important medicinal plant of tropical India as well as subtropical India. It is commonly known as silk cotton tree. Bombax contain species such as $B$. ceiba, $B$. pentandrum, $B$. buonopozense, $B$. costatum, $B$. insigne and many more. These are reported to show antibacterial activity, antihelicobacter pylori activity, and effective in colon motility etc. They also contain phytochemicals such as alkaloids, monoterpene hydrocarbons, glycosides, terpenoids, caproic acid etc. Similarly Phyllanthus species belongs to a family of Euphorbiaceae and is commonly known by the name Bhumi amla. It is also found in the tropical and subtropical part. It contains species such $a s$. amarus, $P$. urinaria, $P$. fraternus, $P$. tenellus, $P$. niruri and many more. These are known to be effective in the treatment of liver diseases, kidney stones, showed antimicrobial, antioxidant activity, etc. These contain phytochemicals such as alkaloids, flavonoids, steroids, coumarin, triterpenes, etc. This review paper aims to present various species of these plants, phytochemicals present and their co-relation for treating very common diseases like thyroid and diabetes mellitus, so that further in vitro and in vivo studies could be performed for exploring their potential.
\end{abstract}

Key Words: Anti-Helicobacter pylori, Bombax species, Phyllanthus species, Phytochemicals

\section{INTRODUCTION}

Diabetes mellitus (DM) and thyroid dysfunctions are considered as some of the most common metabolic disorders across the globe. The prevalence of DM has reached a pandemic proportion. World Health
Organization (WHO) estimated about 180 million people with diabetes and this figure is likely to be more than double to 366 million by 2030 .Similarly thyroid related problems are also increasing every year. As most of the body functions are dependent on the proper working of the thyroid gland, overactive (referred to as hyperthyroid) or underactive (referred to as hypothyroid) condition can create health problems. About 1 to $2 \%$ of the adult population is known to suffer from thyroid problems. In India it is estimated that more than 30 million are suffering from thyroid disease which was based on recent nationwide studies on thyroid disorders among adolescents and young adults in the post salt iodization phase.

"The oldest documentation on human knowledge seems to be Rigveda which was written between4500-1600 B.C. Ayurveda, which is a part of Rigveda, is the foundation of medicinal science of Hindu culture. It deals with particular properties of drugs and various aspects of life science and the art of healing" [1]. "75 - 80\% of Herbal medicine is used by the whole human population which further involving the use of plant extracts and their active constituents which found in this plant. Among 7,000 medicinal plant species recognized globally, about 15,00 plants are systemically used in indigenous system of medicine like Unani, Ayurveda and Siddha" [2]. "With the raising acceptance of herbal medicine as an alternative form of health care, the screening for active compounds of medicinal plants has become very interesting to understand the novel action mechanism" [3-5]. "Bombax is one of the genus which is widely used across the globe for this purpose. Bombax is a genus of tropical and sub tropical trees in the Malvaceae family" [6]. Bombax genus contains many different types of species. Among those, Bombax ceiba is the most common type of species.

Bombax malbaricum DC syn., Salmalia malabarica Schott.and Endl., and BombaxceibaLinn.belongs to the family Bombacaceae. "It is known by different names such as red cotton tree, Indian kapok tree (English), shimul (Bengali), Shalmali (Sanskrit), semul (Hindi), Kondabruga (Telegu), and mullilavu (Malayalam) in distinct languages" [7]. "It is a deciduous tree attaining a height up 
to 40 meters and a girth up to 6 meter or more. It is distributed throughout the hotter parts of the country up to 1500 meter or more in India" [8]. The appearance of this tree is shown in Figure 1.A variety Bombax insigne is shown in Figure 2.

Bark- grey brown or silver grey colored with hard sharp conicles prickles.

Leaves - are large, spreading, glabrous, leaflets lanceolate, 3-7 and margin entire

Flowers - are red and more in quantity, appearing when the tree is bare of leaves, the arrangement of stamen is in bundles of five.

Fruits - The fruits are brown capsule-like up to 15 mm long, filled with numerous black seeds.

Seeds - are generally appears smooth, black or grey fixed in long white wool, which are not in regular in shape, smooth and dense silky hair.

Gum - Light brown to opaque or dark brown called as semul gum [9].

Some other species of Bombax genus are Bombax buonopozense, Bombax costatum, Bombax insigne, Bombax pentandrum L., Bombax albidum, Bombax anceps and many more. Some of these species are explained in this further.

"Bombax pentandrum, commonly known as silk cotton tree, is a perennial shrub prevalent in Central America. Studies by Diomeniet. al.,and Desire et.al., $(\mathbf{2 0 0 6 , 2 0 0 7 )}$ on the leaf and stem bark extracts have shown that the plant has anti-diabetic properties" [10-11].

"Bombax buonopozense [P] Beauv on the other hand is of the family Malvaceae formerly Bombacaceae and is known commonly as Gold coast Bombax or red flowered silk cotton tree.

It is known by the following local names:

Igbo - Akpe

Yoruba - Ponpola

Hausa - Gurjuya, Kurya

Efik - Ukim and

Ijaw - Ido Undu

It is native primarily in West Africa where it is found in rainforests of Sierra Leone in the northwest, east Gabon, typically at elevations of 900 to 1200 meters" [12].

"Bombax costatum is a deciduous tree up to $25 \mathrm{~m}$ high in the savannah region; might be just $6 \mathrm{~m}$ in the sahel region. It is locally called Kuryaa or Gurjiiyaa and Joohi in "Hausa" and "Fulfulde" languages, respectively" [13].
"Bombax insigne syn. Salmalia insignis (Family Bombacaceae) is also known as Shalmali (Sanskrit), Semul-tula (Bengali), Kalilavu (Tamil), Kalilavu (Malayalam), Didu (Andamans) and Shemlo (Gujarati)" [14-15]. The appearance of this plant is shown in figure 2.

"The genus Phyllanthus (Phyllanthaceae) consists of around 1000 species, spread over the African, Australian, American, and Asian continents" [16-17]. "All three important habits, which is, trees, shrubs, and herbs, are seen amongst the Phyllanthus species. Many of the herbs apply to genus Phyllanthus have been shown to include various combinations of secondary metabolites which render them with medicinal assests. The major class of bioactive compounds like alkaloids, flavonoids, lignans, phenols, tannins, and terpenes has been extracted from these herbs" [18]. Most of the Phyllanthus herbs form an integral part of Ayurveda, an Indian system of medicine. By Knowing the importance and potential of these herbs, it is natural that most of the studies are directed towards the phytochemical analysis and pharmacognostics. But, for proper utilization of the herbs for ethnopharmacological research and preparation of herbal medicines, the correct identification of Phyllanthus species is very important. Also, with the developed utilization of these all herbs in pharmaceutical industries, the threat to loss of genetic diversity exists. There is comparatively a lesser number of information focusing on molecular taxonomy for identification of species and interspecific/intraspecific studies of genetic diversity.

\section{LITERATURE REVIEW}

\section{A. Bombax species and their phytochemistry}

\section{Bombax ceiba}

"Ethanolic extracts of Bombax ceiba evaluated strong anti-Helicobacter pylori activities. The minimum inhibitory concentration values of the antiHelicobacter pylori activity given by the ethanolic extracts ranged from 0.64 to $10.24 \mathrm{mg}$ " [19].

"Rani et al,(2004) in their studies showed that the plant extracts (aqueous and methanol) were assayed for their activity against multi-drug resistant Salmonella typhii. Strong antibacterial activity was shown by the methanol extracts of Salmalia malabarica” [20].

Phytochemistry 
"From the roots of $B$. malabaricum new glycosides 3', 4', 5, 7-tetra hydroxyl-6- methoxy flavan-3-o- $\beta$-D glucopyranosyl- $\alpha$-D-xylopyranoside, tracontanol and $\beta$ - sitosterol was isolated. 1, 6-dihydroxy-3- methyl5-isopropyl-7-methoxy-8- naphthalene carboxylic acid (81) lactone was also isolated" [21]. "Mixture of polysaccharide (L-arabinose, D-xylose, with traces of L-rhamnose, uronic acid) along with 2, 3, 4, 6- tetrao-methyl glucose and 2, 3, 6-tri-o-methyl glucose, 2o-methyl glucose and 3-0-methyl glucose were also isolated from roots" [22].

\section{Bombax pentandrum}

"Toxicological studies on the plant revealed its low toxicity profile and showed that it is fairly safe for herbal oral medication" [23]. Agar diffusion technique is frequently used to screen extracts of plant for antimicrobial activity [24], "but it is limited to the generation of preliminary quantitative data" [25-26]. Phytochemical such as tannins are found to be the reason for the pharmacological activities such as stimulation of phagocytic cells, host mediated tumor activity and a wide range of anti-infective actions.

\section{Phytochemistry}

Some of the phytochemicals present in the Bombax pentandrum includes $\beta$-pinene, limonene, 1-methoxy4-(2-propenyl)-benzene, $\alpha$-copaene, pentanoic acid, methyl benzoate, benzyl alcohol, terpinen-4-ol, 1octen-3-ol. These are some of the phytochemicals which are present in the volatile oil of this plant species.

\section{Bombax buonopozense}

"The antidiarrheal activity of the plant extract was not comparable to the standard drug, loperamide, which at present is one of the most efficacious and widely employed antidiarrheal drugs. Loperamide effectively antagonizes diarrheal activity induced by castor oil, prostaglandins or cholera toxin" [27-29]. Further studies revealed that $B$. buonopozense contains many pharmacologically substances which are active and are involved in the treatment of Diarrhea. Some more experiments have to be done to test the mechanism of antidiarrheal activity.

\section{Phytochemistry}

"The crude extract of Bombax buonopozense was subjected to qualitative phytochemical screening according to standard methods" [30]. "Phytochemical screening of the plant extract in the present study revealed the presence of tannins, saponins, steroids, terpenes, alkaloids and flavonoids which have all been reported to possess activity and therefore explain its antidiarrheal action" [31-32].

\section{Bombax insigne}

Morphology of the plant shows that phytochemicals such as flavonoids, alkaloids, tannis, proteins, carbohydrates enhance the pharmacological activities of the Bombax insigne. It also possesses antioxidant activity. The variety is shown in Figure 2.

\section{Phytochemicals}

Phytochemical screening were done for this plant Bombax insigne and some of the phytochemicals were observed such as coumarin, gum and mucilage, alkaloids, glycosides, tannins, terpenoids, flavonoids, phenols, saponins, quinone, Anthroquinone, proteins, carbohydrates and amino acids.

\section{Bombax costatum}

"Several parts of Bombax costatum are used in traditional medicine against variety of illnesses. The bark of both stem and roots are reported to have diuretic properties, and are used in the treatment of skin diseases, epilepsy, insanity, yellow fever and headache; and to promote lactation and wound healing. Previous scientific studies have reported that the fruits of Bombax costatum possess good in vitro antioxidant potentials" [33-34].

\section{Phytochemistry}

Some of the phytochemicals present in the Bombax costatum plant species are palmitic acid, stearic acid, lignoceric acid, caproic acid, oleic acid, rachidic acid, caprylic acid and these are found to be present in the fatty acid of its oil. 


\section{$\underline{\text { Images }}$}

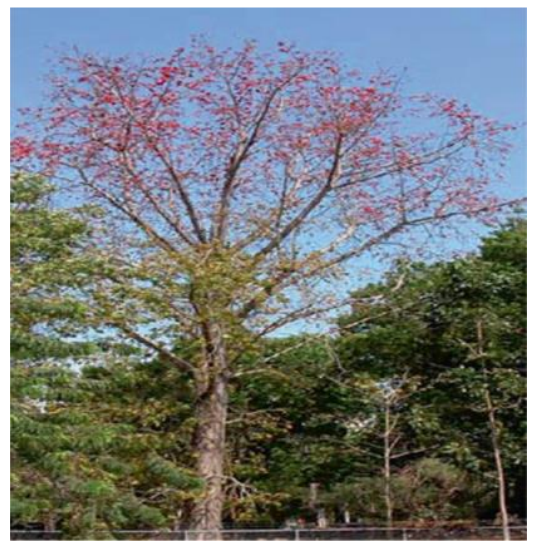

Figure 1: Bombax ceiba tree with flowers (AprMay).

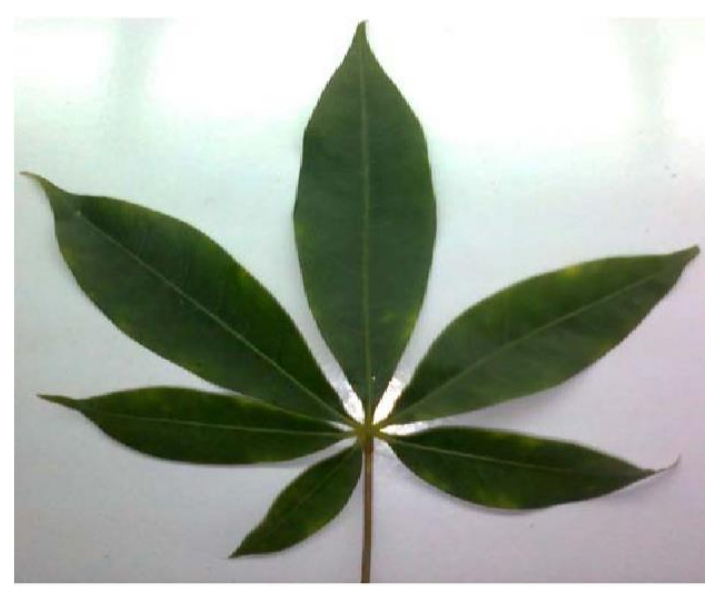

Figure 2: Bombax insigne

\section{Phyllanthus species and their phytochemistry}

\section{Phyllanthus amarus}

"This herb finds its use globally for the treatment of problems like stomach, genitourinary system, liver, kidney, and spleen. It plays important role in Ayurveda, an Indian system of medicine, and is used to treat dysentery, fevers, jaundice, scabies, gastropathy, diarrhoea, menorrhagia, genital infections, ulcers, and wounds" [35]. "Decoctions of entire plants are benefit for treating migraine, jaundice, gonorrhea and syphilis, skin disease, and malaria" [36-40]. The variety is shown in Figure 3.

\section{Phytochemistry}

"The phytochemistry of $P$. amarusis well studied" [35]. "It has the maximum information of pharmaceutically vital key compounds isolated from aqueous or organic solvent extracts. The lignansphyllanthin, hypophyllanthin, niranthin, nirtetralin, virgatusin, and heliobupthalmin lactone are familiar to $P$. amarus, $P$. maderaspatensis, $P$. urinaria, and $P$. virgatus" [41]. "Antibacterial activity has been shown by virgatusin and phyllanthin in P. amarus. Most of the compounds have been identified in $P$. amarus for antioxidant property. In separate studies, the $P$. amarus antiviral property has been associated to the compounds niranthin, nirtetralin, hinokinin, geraniin, and corilagin" [4243].

\section{Phyllanthus urinaria}

"This herb has multiple benefits for most of pharmacognostic properties. Aqueous/methanolic extract of this plant issued for treating cancer" [4446]. Zhonget al. (2013 found that the acetone extract part of the plant has been showed to inhibit herpes simplex virus infection [47]. Lans (2006) in his studies showed that this plant parts have been successfully used in treating hypertension, jaundice, and diabetes [48]. See Figure5.

\section{Phytochemistry}

"Rutin and quercetin are discovering in $P$. urinaria but have been shown to exhibit antiviral property. It may be worthwhile to consider the act of rutin and quercetin for antioxidant property in $P$. urinaria. Anti-inflammatory activity in $P$. urinariais attributed to the phytochemicals, phyltetralin, phyllanthin, quercetin, rutin, rhamnocitrin, and $\beta$-sitosterol" [49].

\section{Phyllanthus fraternus}

"Traditionally, in India, the herb was considered as a mild laxative, to remove worms and intestinal gas. Figure 6 could be seen. The plant parts are used for treating many types of biliary and urinary conditions like gall bladder, kidney stones, and bacterial infections such as cystitis, prostatitis, viral infections, hepatitis, flu, tuberculosis, liver diseases, anemia, veneral diseases, and urinary tract infections" [50]. "The antimicrobial property of $P$. fraternus has been reported" [51].

\section{Phytochemistry}

"In $P$. fraternus, phyllanthin is not found, whereas have reported that both phyllanthin and hypophyllanthin are present in $P$. amarus and $P$. fraternus but the amount of these two lignans varies substantially in the two species. Existence of the 
lignan, phyltetralin, is common to $P$. amarus, $P$. fraternus, $P$. maderaspatensis, $P$. virgatus, and $P$. urinaria” [52].

\section{Phyllanthus tenellus}

"Extracts of fresh and dried plants have antiviral and antimicrobial property" [53-54]. "The callus extracts of this herb have potential analgesic properties against neurogenic and inflammatory pain" [55]. "Although this herb is beneficial for diabetes and treatment of hepatitis, urolithiasis and bowel diseases, it induces depression, spasms, increased respiratory rate, and dyspepsia, as shown from experiments on mice" [56]. See Figure 7.

\section{Phytochemistry}

Some of the phytochemicals present in the Phyllanthus tenellus are hinokinin, Niranthin, nirtetralin, pinocembrin-7-O-[3-O-galloyl-4,6-(S)hexahydroxydiphenoyl]- $\beta$-Dglucose, Pinocembrin-7O-[4,6-(S)-hexahydroxydiphenoyl]- $\beta$-D-glucose.

\section{Phyllanthus niruri}

"Phyllanthus niruri has broad medicinal properties and has long history in the health care system of tropical countries. The plant is recognized in traditional health care systems. P.niruri is commonly called as "stone breaker". However, there is a lot of confusion about this species recognition. Phyllanthus niruri is utilized as a folk medicine for treating kidney stones, gallbladder stones, liver related diseases such as liver cancer $\&$ jaundice, apart from these it is also administered for diuretic, hypertension and hypoglycemic cases and it also shows antiinflammatory, anti-tumor, antinociceptive and antioxidant properties" [57]. Figure 5 shows the picture of plant.

\section{Phytochemistry}

Phytochemical screening of this plant was done and some of the phytochemicals present in this plant are tannins, glycosides, steroids, phenyl propanoids, lignans, phyllanthin, alkaloids, niruriside, ellagitannins, ricinolic acid, hypophyllanthin, triterpenes, phyltetralin.

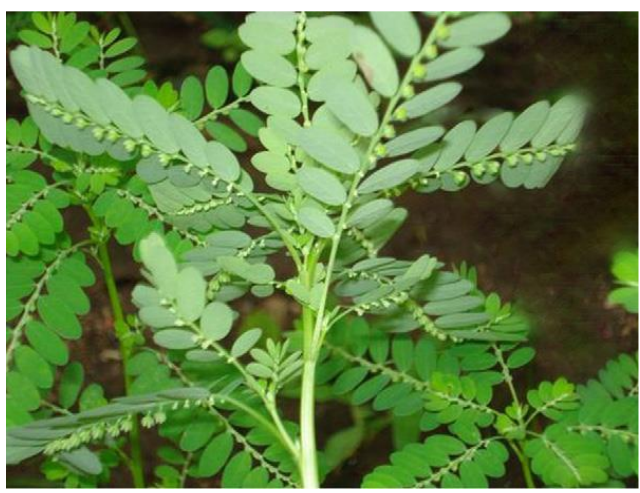

Figure 3: Phyllanthus amarus

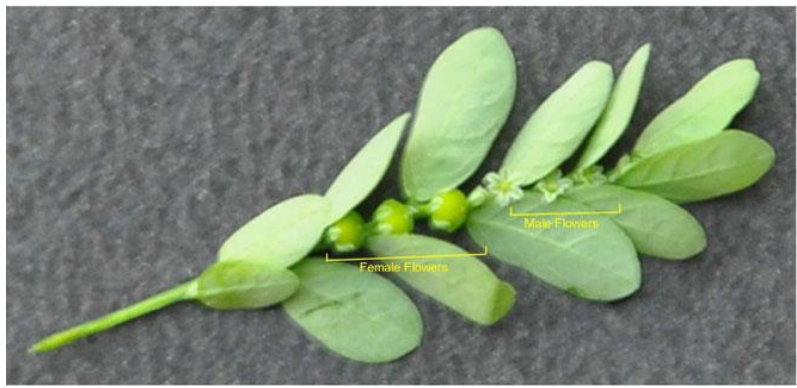

Figure 4: Phyllanthus niruri

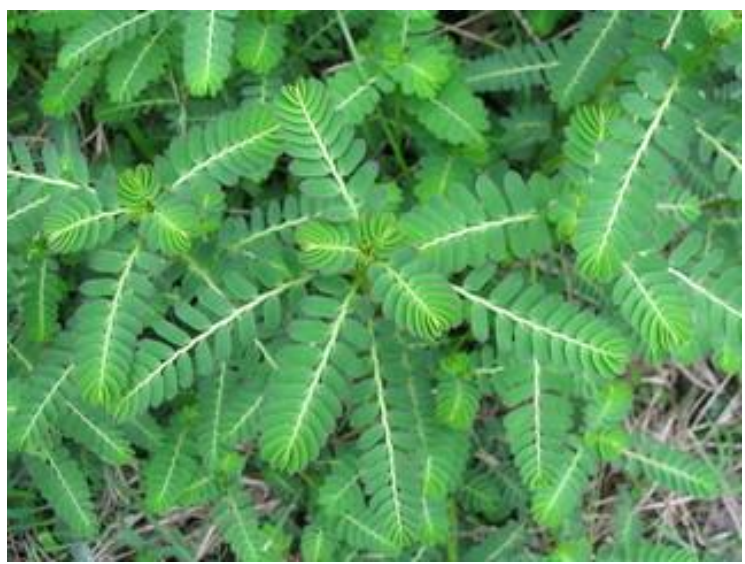

Figure 5: Phyllanthus urinaria 


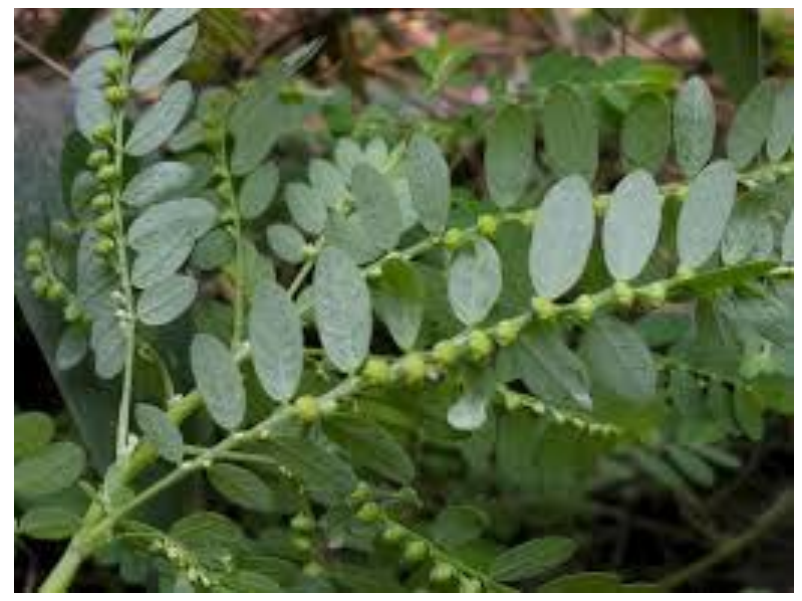

Figure 6: Phyllanthus fraternus

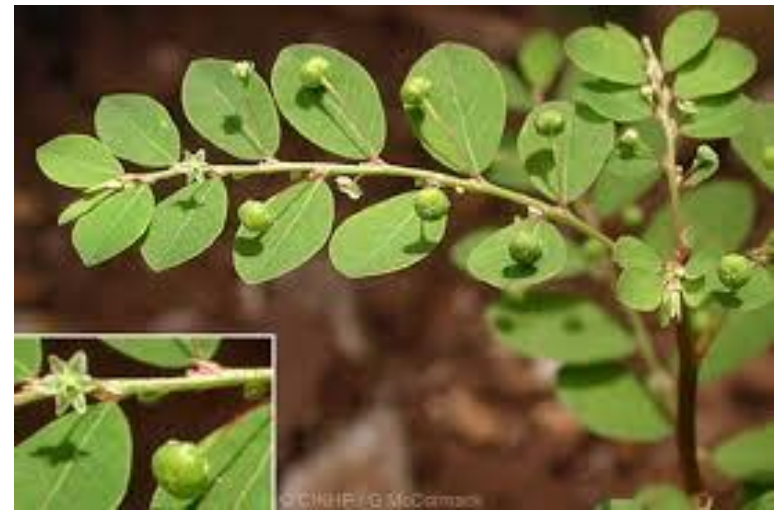

Figure 7: Phyllanthus tenellus

\section{CONCLUSION}

Diabetes and Thyroid especially hypothyroid problems are very prevalent among the population. Although both have allopathic drugs to be taken as orally, but as we are aware that these drugs show side effects on major internal organs like heart and kidneys. So herbal formulations are very much required.

Bombax and Phyllanthus species are commonly found all over the world so their use is cost effective. Also as we have discussed they possess so many phytochemicals which act as antioxidant. They both have various activities like anti-helicobactor activity, antibacterial activity, antimicrobial activity, antiinflammatory activity, etc. They both are involved in the treatment of human diseases. They both have economic as well as ecological importance and they should be sustained for ecological prospective. They are of great use for curing different types of diseases. They have been used from generation to generation for the treatment of various diseases. Both the plants possess potential to overcome most of the health problems in a human body. Both contain important phytochemicals such as alkaloids, steroids, tannins, flavonoids, etc.

On one hand Bombax species possesses potential to cure diabetes, Phyllanthus have potential to cure liver ailments. Some studies also showed that Bombax species could be used for thyroid problems. There are data which showed correlation between diabetes and thyroid, so this review explore the possibility of using both the species, that to P.niruri, and B.ceiba as anti thyroid drug. Many other diseases could also be cured using these species either alone or in combination. Further in vitro and in vivo studies should be carried out for making formulations of these plant parts to cure common diseases majorly for Diabetes and Thyroid, to overcome the side effects of allopathic medicines.

\section{ACKNOWLEDGMENT}

The research article is purely theoretical based and did not receive any financial support from funding agencies.

\section{REFERENCES}

1) Rastogi, R.P., \&Mehrotra, B.N. (2002), Glossary of Indian medicinal plants, National Institute of Science Communication, New Delhi, India.

2) Akerele, O. (1993), Summary of WHO guidelines for the assessment of Herbal medicines, Herbal Gram, vol. 22, (pp.13-28).

3) Murthy, K.N., Jayaprakasha, G.K., \&Singh, R.P. (2002), Studies on antioxidant activity Pomegranate peel extracts using in vivo models, $\mathrm{J}$ Agric Food Chem, vol. 50, (pp.

4791-4795).

4) Badami, S., Gupta, M.K., \&Suresh, B. (2003), Antioxidant activity of the ethanolic extract of Striga orobanchioides, J Ethnopharmacol, vol. 85, (pp. 227-230).

5) Meurer-Grimes, B., McBeth, D.L., Hallihan, B., \&Delph, S. (1996), Antimicrobial activity in medicinal plants of the Scrophulariaceae and Acanthaceae, Int J Pharmacog, vol. 34, (pp. 243248). 
6) Mabberley, D.J. (2008), Mabberley's Plant-Book, A Portable Dictionary of Plants, $3^{\text {rd }}$ ed. Cambridge, UK, Cambridge University Press.

7) Vaidyaratnam, P.S. (1997), Indian Medicinal Plants: A Compendium of 500 Species. Kottakkal, Orient Longman Publishing, vol. 3, (pp. 222).

8) Government of the Health and Family Welfare (2007), The Ayurvedic Pharmacopoeia of India. Part I. New Delhi, Government of the Health and Family Welfare, vol. 3, (pp. 183-184).

9) Warier, P.K. (1994), Indian Medicinal Plants a compendium of 500 species., Orient Longman private limited Chennai, Forth edition, vol. 104, No. 2, (pp. 224-89).

10) Diomeni, D.G., Tedong, H.O., Asongalem. A.S., Dimo, T.S., Sokeng, S.D., \&Kamtchouing, M.P. (2006), Effects of the methylene chloride/methanol extract of root bark of Ceiba pentandra in normal and streptozotocin-induced diabetic rats, Ind. J. Pharmacol, vol. 38, No. 3, (pp. 194-197).

11) Désiré, P., Dzeufiet, D., Dieudonné, Y., Ohandja, L.T., Emmanuel, A. A., Théophile D, et al. (2007), Antidiabetic effect of Ceiba pentandra extract on streptozo-tocin-induced non-insulindependent diabetic (niddm) rat, Afr. J. Trad. Comp. Alt. Med., vol. 4, No. 1, (pp. 47-54).

12) Beentje, H., \&Smith, S. (2001), Plant systematic and Phytogeography for the understanding of African Biodiversity, Systematic and Geography of plants, vol. 71, No. 2, (pp. 234-286).

13) Nuhu, M., Abdullahi, H., Yaro, A., \& Balarabe, N. (2018), Bombax costatum Pellegr. and Vuillet stem bark extract prevents paracetamol and carbon tetrachloride-induced liver injury in rats, Tropical Journal of Natural Product Research, vol. 2, No. 5, (pp. 220-226).

14) Kirtikar, K.R., \&Basu, B.D. (2005), Indian medicinal plants. edn 2, Dehradun. International Book Distributors, vol. 1, (pp 354).

15) Anonymous. (1988), Wealth of India: Raw materials, Council of Scientific and Industrial Research, New Delhi, vol. 2, (pp. 185).
16) Unander, D.W., Webster, G.L., \&Blumberg, B.S. (1995), Usage and bioassays in Phyllanthus (Euphorbiaceae) - IV: clustering of antiviral uses and other effects, Journal of Ethnopharmacology, vol. 45, No. 1, (pp. 1-18).

17) Webster, G.L. (1994), Synopsis of the genus and suprageneric taxa of Euphorbiaceae, Annals of the Missouri Botanical Garden, vol. 81, (pp. 33144).

18) Nahar, L., Sarker, S.D., \&Delazar, A. (2011), Phytochemistry of the genus Phyllanthus, in Phyllanthus Species, Scientific Evaluation and Medicinal Applications, eds. Kuttan R, Harikumar KB, London, UK. Taylor and Francis Group, CRC Press, (pp. 119-138).

19) Wang, Y.C., \&Huang, T.L. (2005), Screening of anti-Helicobacter pylori herbs deriving from Taiwanese folk medicinal plants, FEMS Immunol Med Microbiol, vol. 43, (pp. 295-300).

20) Rani, Phulan, \&Khullar N. (2004), Antimicrobial evaluation of some medicinal plants for their antienteric potential against multi-drug resistant Salmonella typhii, Phytotherapy Research, vol. 18, No. 8, (pp. 670-673).

21) Compendium of Indian Medicinal Plants, vol. 2, (pp. 102-105).

22) Haq, Q.N., \&Gomes, J. (1973), Water soluble polysacchride from the roots of Salmalia malabarica, Bangladesh J. Sci. Ind. Res., vol. 8, No. (1-4), (pp. 16-20).

23) Sarkiyayi, M., Ibrahim, M.S., \&Abubakar, M.M. (2009), Toxicological studies of Ceiba pentandra, Afr. J. Biochem Res, vol. 3, No. 7, (pp. 279-281).

24) Smith-Palmer, A., Stewart, J., \&Fyfe, L. (1998), Antimicrobial properties of plant essential oils and essences against five important food-borne pathogens, Lett. Appl. Microbiol, vol.26, (pp. 118-122).

25) Janssen, A.M., Scheffer, J.J.C., \&Baerheimsvendsen, A. (1987), Antimicrobial activity of essential oils: a 1976-86 literature review. Aspects of the test methods, Planta Medica, vol. 53, (pp. 395-398).

26) Rios, J.L., Recio, M.C., \&Villar, A. (1988), Screening methods for natural products with 
antimicrobial activity: a review of the literature, $\mathrm{J}$. Ethnopharm, vol. 23, (pp. 127-149).

27) Karim, S.M.M., \&Adaikan, P.G. (1977), The effect of loperamide on prostaglandin-induced diarrhoeal in rat and man, Prostaglandins, vol. 13, (pp. 321-331).

28) Farack, U.M, Kantz, U., Loescke, K. (1981), Loperamide reduces the intestinal secretion but not the mucosal cAMP accumulation induced by cholera toxin, Naunyn Schmiedebergs Arch Pharmacol., vol. 317, (pp. 178-179).

29) Dubost, G. (1984), Comparison of diets of frugivorous forest mammals of Gabon, $\mathrm{J}$ Mammalogy, vol. 65, (pp. 298-316).

30) Trease, G.E., \&Evans, M.C.(1996), Textbook of Pharmacognosy, 14th ed. London. Bailliere Tindal, (pp. 565-566).

31) Galvez, J., Zarzuelo, A., Crespo, M.E., Lorente, M.D., Ocete, M.A., \&Jimenez, J. (1993), Antidiarrhoeal activity of Euphorbia hirta isolation of an active flavonoidal constituent, Planta Med., vol. 59, (pp. 33-36).

32) Longanga, O.A., Vercruysse, A., \&Foriers, A. (2000), Contribution to the ethnobotanical, phytochemical and pharmacological studies of traditionally used medicinal plant in the treatment of dysentery and diarrhea in Lomela area, Democratic Republic of Congo (DCR), J Ethnopharmacol, vol. 71, (pp. 411-413).

33) Burkill, H.M. (1985), The Useful Plants of West Tropical Africa, 2nd ed., Kew, Richmond, UK. Families A-D. Royal Botanic Gardens, vol. 1.

34) Cook, J.A, VanderJagt, D.J., Dasgupta, A., Mounkaila, G., Glew, R.S., Blackwell, W, et al. (1998), Use of the Trolox assay to estimate the antioxidant content of seventeen edible wild plants of Niger, Life Sci., vol.63, No. 2, (pp. 105110).

35) Patel, J.R., Tripathi, P., Sharma, V., Chauhan, N.S., \&Dixit, V.K. (2011), Phyllanthus amarus: ethnomedicinal uses, phytochemistry and pharmacology: a review, Journal of Ethnopharmacology, vol. 138, No. 2, (pp. 286313).
36) Kala, C.P., Dhyani, P.P., Sajwan, B.S. (2006), Developing the medicinal plants sector in northern India: challenges and opportunities, J Ethnobiol and Ethnomed., vol. 2, article 32.

37) Udayan, P.S., Tushar, K.V., George S., et al. (2007), Ethnomedicinal information from Kattunayakas tribes of Mudumalai Wildlife Sanctuary. Nilgiris district, Tamil Nadu, Indian J of Traditional Knowledge, vol. 6, (pp. 574-578).

38) Samy, R.P., Pushparaj, P.N., \&Gopikrishnakone, P.A. (2008), Compilation of bioactive compounds from Ayurveda, Bioinformation, vol. 3, No. 3, (pp. 100-110).

39) Chenniappan, K., \& Kadarkarai, M. 2(010), In vitro antimalarial activity of traditionally used Western Ghats plants from India and their interactions with chloroquine against chloroquineresistant Plasmodium falciparum, Parasitology Research, vol. 107, No. 6, (pp. 13511364).

40) Upadhyay, B., Parveen, P., Dhaker, A.K., \& Kumar, A. (2010), Ethnomedicinal and ethnopharmaco-statistical studies of Eastern Rajasthan, India, Journal of Ethnopharmacology, vol. 129, No. 1, (pp. 64-86).

41) Shanker, K., Singh, M., Srivastava, V., Verma, R., Gupta, A., \&Gupta M. (2011), Simultaneous analysis of six bioactive lignans in Phyllanthus species by reversed phase hyphenated high performance liquid chromatographic technique, ActaChromatographica, vol. 23, No. 2, (pp. 321337).

42) Huang, R.L., Huang, Y.L., Ou, J.C., Chen, C.C., Hsu, F.L., \&Chang, C. (2003), Screening of 25 compounds isolated from Phyllanthus species for anti-human hepatitis B virus in vitro, Phytotherapy Research, vol. 17, No. 5, (pp. 449453).

43) Notka, F., Meier, G., \&Wagner, R. (2004), Concerted inhibitory activities of Phyllanthus amarus on HIV replication in vitro and ex vivo, Antiviral Research, vol. 64, No. 2, (pp. 93-102).

44) Huang, S.T., Yang, R.C., \&Pang, J.H.S. (2004), Aqueous extract of Phyllanthus urinaria induces apoptosis in human cancer cells, American Journal of Chinese Medicine, vol. 32, No. 2, (pp. 175-183). 
45) Huang, S.T., Pang, J.H.S., \&Yang, R.C. (2010), Anti-cancer effects of Phyllanthus urinaria and relevant mechanisms, Chang Gung Medical Journal, vol. 33, No. 5, (pp. 477-487).

46) Tang, Y.Q., Jaganath, I.B., \&Sekaran, S.D. (2010), Phyllanthus spp. induces selective growth inhibition of PC-3 and MeWo human cancer cells through modulation of cell cycle and induction of apoptosis, PloS ONE, vol. 5, No. 9, article e12644.

47) Zhong, M., Xiang, Y., Qiu, X., et al. (2013), Natural products as a source of anti-herpes simplex virus agents, RSC Advances, vol. 3, No. 2, (pp. 313-328).

48) Lans, C.A. (2006), Ethnomedicines used in Trinidad and Tobago for urinary problems and diabetes mellitus, Journal of Ethnobiology and Ethnomedicine, vol. 2, article 45.

49) Fang, S.H., Rao, Y.K., \&Tzeng, Y.M. (2008), Anti-oxidant and inflammatory mediator's growth inhibitory effects of compounds isolated from Phyllanthus urinaria, Journal of Ethnopharmacology, vol. 116, No. 2, (pp. 333340).

50) Nishiura, J.L., Campos, A.H., Boim, M.A., Heilberg, I.P., \&Schor, N. (2004), Phyllanthus niruri normalizes elevated urinary calcium levels in calcium stone forming (CSF) patients, Urological Research, vol. 32, No. 5, (pp. 362366).

51) Chanda, S., Kaneria, M., \&Vaghasiya, Y.K. (2011), Evaluation of antimicrobial potential of some Indian medicinal plants against some pathogenic microbes, Indian Journal of Natural Products and Resources, vol. 2, No. 2, (pp. 225228).

52) Tripathi, A.K., Verma, R.K., Gupta, A.K., Gupta, \&Khanuja, S.P.S. (2006), Quantitative determination of phyllanthin and hypophyllanthin in Phyllanthus species by high-performance thin layer chromatography, Phytochemical Analysis, vol. 17, No. 6, (pp. 394-397).

53) Ign’acio, S.R.N., Ferreira, J.L.P., Almeida, M.B., \&Kubelka, C.F. (2001), Nitric oxide production by murine peritoneal macrophages in vitro and in vivo treated with Phyllanthus tenellus extracts,
Journal of Ethnopharmacology, vol. 74, No. 2, (pp. 181-187).

54) Oliveira, D.F., Pereira, A.C., Figueiredo, H.C.P., et al. (2007), Antibacterial activity of plant extracts from Brazilian southeast region, Fitoterapia, vol. 78, No. 2, (pp. 142-145).

55) Santos, A.R.S., Filho, V.C., Niero, R., et al. (1994), Analgesic effects of callus culture extracts from selected species of Phyllanthus in mice, Journal of Pharmacy and Pharmacology, vol. 46, No. 9, (pp. 755-759).

56) Silva, T.C.D.L., Veras, F.J., Souza, I.A., et al. (2012), Acute toxicity study of stone-breaker (Phyllanthus tenellus Roxb.), Revista deCi^enciasFarmac`euticasB'asica e Aplicada, vol. 33, No. 2, (pp. 205-210).

57) Bagalkotkar, G., Sagineedu, S.R., Saad, M.S., \&Stanslas, J., (2006), Phytochemicals from Phyllanthus niruri Linn. and their pharmacological properties: a review, J. Pharm. Pharmacol, vol. 58, (pp. 1559-1570). 